\title{
ON THE NORMAL SEX RATIO AND THE SIZE OF THE LITTER IN THE ALBINO RAT (MUS NORVEGICUS ALBINUS)
}

\author{
HELEN DEAN KING AND J. M. STOTSENBURG \\ From the Wistar Institute of Anatomy and Biology \\ ONE FIGURE
}

Literature dealing with the early development of the albino rat contains references to but two papers that give information regarding the normal sex ratio and litter size in this animal (Cuénot '99; King '11). Marked differences in the results of these two sets of investigations, which were made on relatively small numbers of individuals, render it necessary that a large series of observations should be recorded in order to furnish adequate standards by which one can judge the effects of experiments aiming to modify the sex ratio or to alter the fertility of the albino rat. To supply the material for such standards the data given in the present paper were collected.

All of the records given are of litters cast by stock albino rats kept in the animal colony of The Wistar Institute. During the period when the data were being collected (1911-1914) all of the animals used for breeding were subjected to similar environmental conditions, and they all were fed on a mixed diet that experience has shown is necessary if rats are to be kept in good condition for any length of time.

THE NORMAL SEX RATIO IN THE ALBINO RAT

Practically all of the data were obtained by examining litters at or very shortly after their birth, since the sexes can readily be distinguished at this time as Jackson ('12) has shown. The removal of the young rats from the nest entails some risk that the mother will not care for them after they are replaced, but it is necessary that the records be taken at this time if one wishes 
an accurate determination of the sex ratio or of the litter size. Not infrequently litters contain one or more stillborn young which are usually eaten by the mother within a few hours after their birth. Often, too, some individuals in the litter, particularly if the litter is large, will be killed by the mother when they are several days old, or if one or more of the young rats in a large litter are constitutionally weak they will die from lack of nourishment, being unable to cope with their stronger brothers in their efforts to obtain food.

No attempt was made to obtain the sex records for all of the litters of stock albino rats that were born in the colony during the years 1911-1913. The data that were collected during this period have been grouped together, according to the months when the litters were cast, and are given in table 1 .

TABLE 1

Showing the sex ratios and the average number of young in litters of stock albino rats born during 1911-1913. Data arranged according to the months when the litters were cast

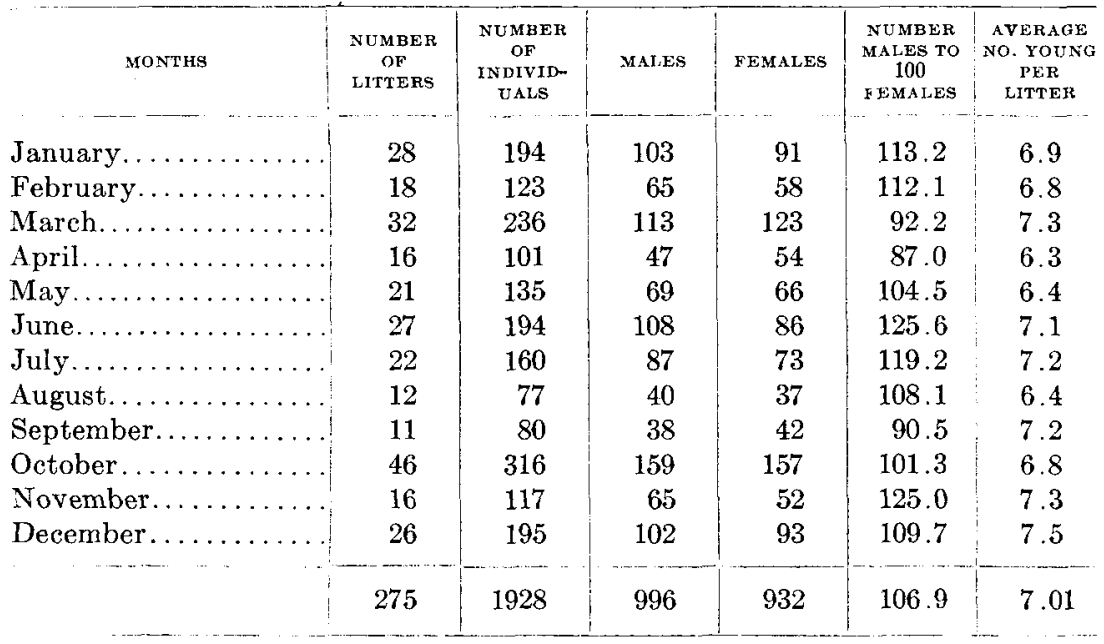

One fact clearly brought out in the above table is that there is no restricted breeding season for the albino rat. Litters are cast during every month of the year, but, as the records for many thousands of litters show, relatively more litters are pro- 
duced in the spring than during other seasons of the year. In table 1 the sex ratios for the different groups of litters do not show a very great range of variation considering the small number of litters involved. The highest sex ratio is that for the 27 litters cast during the month of June; the lowest sex ratio is found in the litters of the April group. For the entire series of 275 litters the sex ratio is 106.9 males to 100 females.

During the year 1914 an attempt was made to obtain the sex data for as many as possible of the litters of stock albino rats born in the colony. The cages containing the breeding animals were examined nearly every day throughout the year and practically all of the litters cast were recorded. The data obtained, arranged according to the months when the litters were cast, are given in table 2 .

TABLE 2

Showing the sex ratios and the average number of young in litters of stock albino rats born during 1914. Data arranged according to the months when the litters were cast

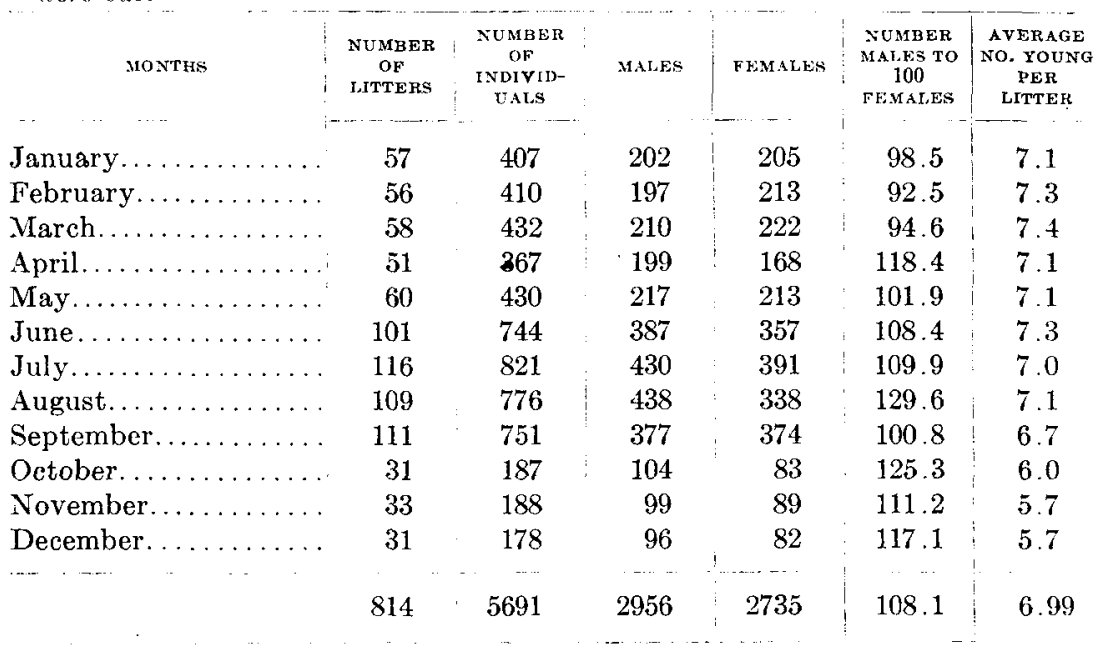

Although the number of records taken during the year 1914 is about three times greater than that collected during the period 1911-1913, the range of variation in the sex ratios of the litters cast during the various months is only slightly greater than that given in table 1 . The lowest sex ratio in this series 
of records is found among the litters cast in February; the highest sex ratio occurs in the litters born in August. The sex ratio of the 814 litters examined during the entire year is 108.1 males to 100 females. This sex ratio is remarkably close to that found in the 275 litters previously recorded (table 1 ).

A summary for all of the data collected is given in table 3 . In order to give equal value to the two sets of records the sex ratios in this table, and also the averages for the size of the litters cast in the various months, represent the arithmetical mean of the records as given in table 1 and in table 2; they have not been computed in any instance on a litter basis.

TABLE 3

A combination of the data given in table 1 and in table 2

\begin{tabular}{|c|c|c|c|c|c|c|}
\hline MONTHS & $\begin{array}{c}\text { NUMBER } \\
\text { OF } \\
\text { LITTERS }\end{array}$ & $\begin{array}{c}\text { NUMBER } \\
\text { OF } \\
\text { INDIVID- } \\
\text { UALS }\end{array}$ & MALES & FEMALES & $\begin{array}{c}\text { NOMBER } \\
\text { MALES TO } \\
100 \\
\text { FEMALES }\end{array}$ & $\begin{array}{c}\text { AVERAGE } \\
\text { NO. YOUNG } \\
\text { PER } \\
\text { LTTTER }\end{array}$ \\
\hline January ........... & 85 & 601 & 305 & 296 & 105.7 & 7.0 \\
\hline February...... & 74 & 533 & 262 & 271 & 102.3 & 7.0 \\
\hline March.... & 90 & 668 & 323 & 345 & 93.4 & 7.3 \\
\hline April... & 67 & 468 & 246 & 222 & 102.7 & 6.7 \\
\hline May....... & 81 & 565 & 286 & 279 & 103.2 & 6.7 \\
\hline June.... . & 128 & 938 & 495 & 443 & 116.9 & 7.2 \\
\hline July. ............ & 138 & 981 & 517 & 464 & 114.6 & 7.1 \\
\hline August............ & 121 & 853 & 478 & 375 & 118.8 & 6.7 \\
\hline September.......... & 122 & 831 & 415 & 416 & 95.6 & 6.9 \\
\hline October............ & 77 & 503 & 263 & 240 & 113.3 & 6.4 \\
\hline November........... & 49 & 305 & 164 & 141 & 118.1 & 6.5 \\
\hline December.......... & 57 & 373 & 198 & $17 \tilde{5}$ & 113.4 & 6.6 \\
\hline & 1089 & 7619 & 3952 & 3667 & 107.5 & 7.0 \\
\hline
\end{tabular}

As arranged in table 3, the data show that the sex ratios are somewhat higher in the litters cast during the latter part of the year than in those cast in the early part of the year. With the exception of the record for March the sex ratios for the litter groups from January to May show a variation of less than three points; and the sex ratios for the litters cast from June to December, omitting the record for September, vary less than four points. The pronounced drop in the sex ratio for the litters produced,during September is found in both sets of records, and at present there is no satisfactory explanation for it. 
In the total of 1089 litters examined there were 3952 males and 3667 females, giving a sex ratio for the series of 107.5 males to 100 females. This sex ratio is somewhat higher than that given by Cuénot, who found in 30 litters of albino rats a sex ratio of 105.6 males to 100 females, but it is practically the same as that given by King ('11) for 80 litters of albino rats (107.3 males to 100 females). The sex ratio found among adult rats is doubtless considerably lower than that given above, as growth experiments with the albino rat at present under way seem to indicate that female rats, as a general thing, live longer than male rats and show somewhat less susceptibility to disease at all stages of their growth.

It would be futile to make a comparison between the sex ratios of the various litter groups owing to the inequality in the number of litters recorded for the different months. For the purpose of a somewhat closer analysis than that given above, the two sets of records have been grouped in table 4 according to the season of the year when the litters were cast. The averages given for the two sets of records were obtained in the same manner as were the averages in table 3 .

TABLE 4

Showing the data for sex ratios and size of the litters in the albino rat arranged according to the season of the year when the litters were cast

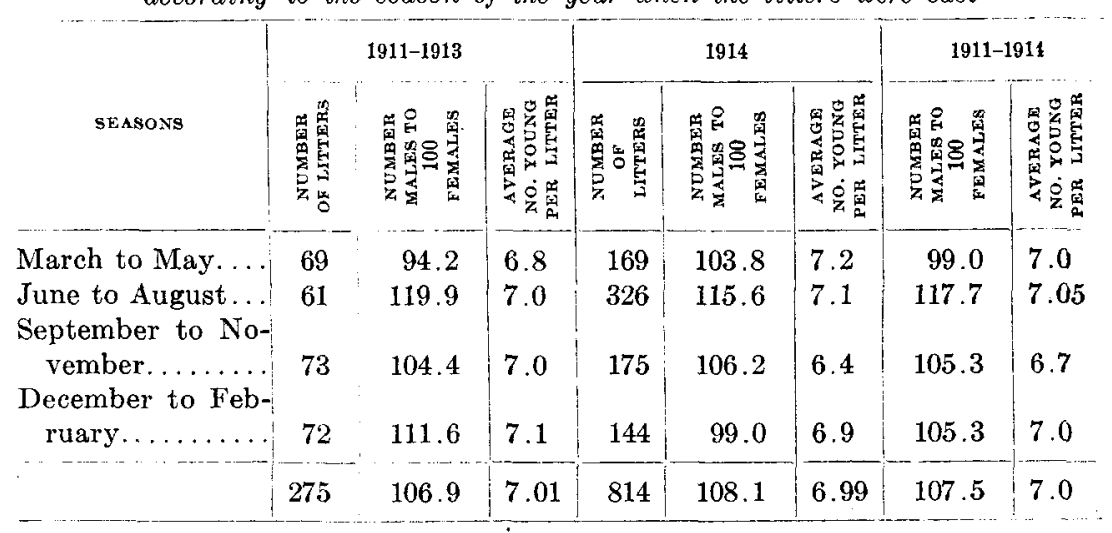

There is a very striking agreement between the corresponding sex ratios for the two sets of records, as is shown in table 4. In each case the sex ratio for the litters cast in the spring 


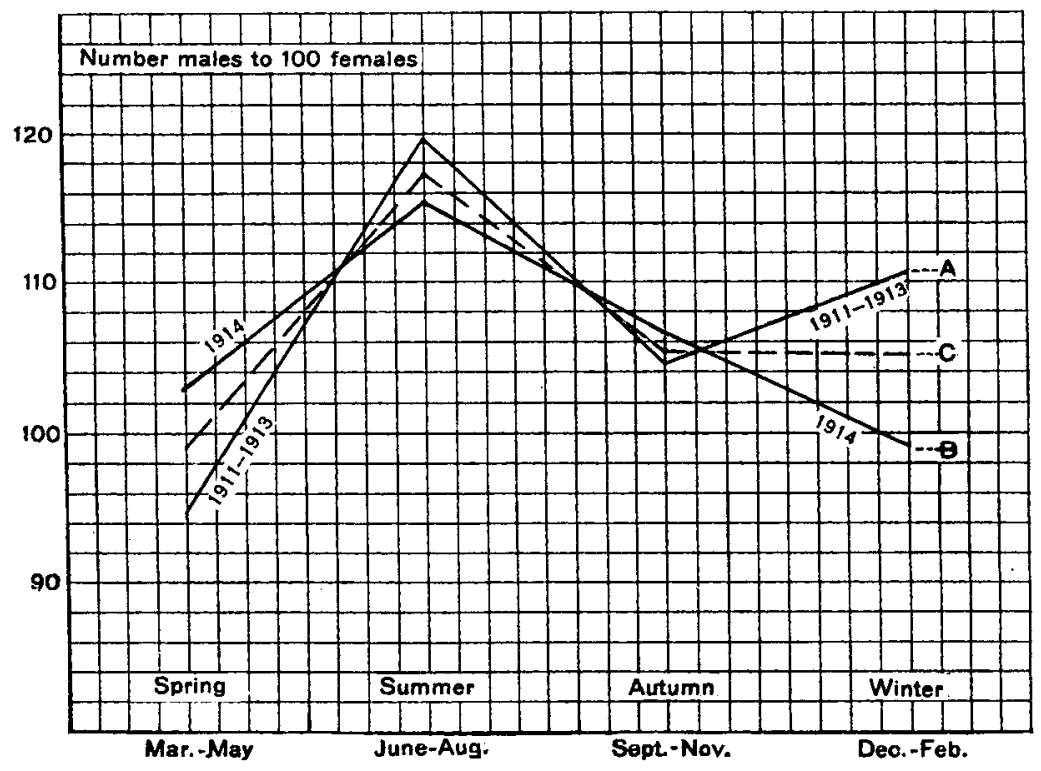

Fig. 1 Graphs showing variations in the sex ratio of the albino rat at different seasons of the year. A, graph constructed from data for litters cast during 1911-1913; B, graph constructed from data for litters cast during the year 1914; $\mathrm{C}$, graph constructed from the averages for the two sets of data

is considerably below the normal sex ratio of 107 males to 100 females; the average for the two groups giving a sex ratio of only 99.0 males to 100 females. Each set of data shows likewise a sharp rise in the sex ratios of the litters born during the summer months and then a drop to below the normal ratio for the litters born in the fall. The two sets of records for the litters cast in the winter months do not, for some reason, show the same agreement as those for the litters produced in other seasons of the year, as in one case the sex ratio is somewhat above the normal and in the other case it is below the normal.

Figure 1 shows graphs, constructed from the data given in table 4, which bring out very clearly the changes in the sex ratio that are found to occur among rats born at different seasons of the year.

Judging from observations and from the records for several thousand litters cast in our colony during the past six years, 
the rat breeds more readily in the spring than in any other season of the year, and there is a second, less pronounced, period of sexual activity in the early fall. The lowest points in the graphs shown in figure 1 are found to coincide with the period in which the greatest sexual activity occurs. Lacking adequate means for heat regulation the rat suffers greatly from heat during the summer months, and for years the highest mortality among the animals in our colony has occurred in July and in August while relatively fewer litters are produced at this time than at other seasons of the year. It is during the hot weather when the breeding animals are not in the best physical condition that the litters produced show the highest sex ratio, as is indicated by the graphs in figure 1 .

The seasonal variation in the sex ratios that is shown by these records cannot be ascribed to environmental conditions other than temperature, since the routine of caring for the animals in our colony is the same throughout the year and there is no change in the character of the food.

That the sex ratios in various mammals seem to show a pronounced variation at different seasons of the year has long been known. From the large body of statisties examined by Düsing ('83) it appears that relatively more boys are born during the winter than during the summer months. Table 5, compiled from data collected by Wilckens ('86) and by Heape ('08), shows the apparent seasonal variation in the sex ratio that occurs in the young of various kinds of domestic animals.

TABLE 5

Showing seasonal variations in the sex ratios of some domes tic animals. Data collected by Wilckens and by Heape

\begin{tabular}{|c|c|c|c|c|}
\hline \multirow[b]{2}{*}{ ANIMALS } & \multirow{2}{*}{$\begin{array}{c}\text { NUMBER } \\
\text { INDIVIDUALS }\end{array}$} & \multicolumn{3}{|c|}{ NUMBER MALES TO 100 FEMALES } \\
\hline & & $\begin{array}{c}\text { Birth in warm } \\
\text { mos. }\end{array}$ & $\begin{array}{l}\text { Birth in cold } \\
\text { mos. }\end{array}$ & $\underset{\text { Bear }}{\text { Birth during entire }}$ \\
\hline Horses. & 16,091 & 96.6 & 97.3 & 97.0 \\
\hline Cattle. . & 4,900 & 114.1 & 103.0 & 107.3 \\
\hline Sheep. ......... & 6,751 & 102.9 & 94.0 & 97.4 \\
\hline Swine......... & 2,357 & 115.0 & 109.3 & 111.8 \\
\hline Greyhounds.... & 17,838 & 116.3 & 122.1 & 118.5 \\
\hline
\end{tabular}


Except in the dog, and in the horse where these statistics are at variance with those collected by Schlechter ('84), the sex ratios as given in table 5 are relatively high among the animals born in the warm months and correspondingly low where the births occurred during the cold months. To be available for analysis by any current theory of sex-determination, however, these records would have to be arranged according to the time when conception occurred, since it seems most probable that sex is determined at or before the time of the fertilization of the ovum and cannot be altered by the nutritive or other environmental conditions to which the embryo is subjected. The gestation period in the rat is so short, only 21 days, that the time of conception and the time of birth may be said to take place in the same season of the year. Since the gestation periods in the various animals for which sex ratios are given in table 5 vary so greatly, the sex records cannot be arranged on any basis except that of the time of birth, and they are of value, therefore, merely as indicating that there is apparently a seasonal variation in the sex ratio of other animals as well as in that of the albino rat.

If it can be shown by a sufficiently large body of statistics that the sex ratio in various animals changes in a definite direction with the time of year at which conception occurs it will indicate that some metabolic process occurs in one or the other or in both of the parent organisms at stated periods which tends to swing the sex ratio in one direction rather than in the other. Assuming that sex is determined by the chromatin constitution of the spermatozoan that fertilizes the egg, we must add to this theory the probability that some form of chemical attraction or repulsion exists between each ovum and one kind of spermatozoan in order to account for the constantly increasing mass of evidence that under changed environmental conditions sex ratios in various animals can be altered in a definite direction. Chance, therefore, cannot play as important a rôle in the process of sex-determination as some investigators have maintained, and any egg is not fertilized by any spermatozoan that happens to come in contact with it. The laws of chance, according to our 
present conception, are not subject to periodic changes in their action, and while they offer a very attractive explanation for the existence of an equality of the sex in certain species, they utterly fail to explain sex ratios that vary in a definite direction, whether as the result of seasonal changes or as the outcome of experimental attempts to modify the sex ratio.

THE EFFECTS OF THE AGE OF THE MOTHER ON THE SEX RATIO OF HER YOUNG

It has been stated by many investigators that the age of the mother has a pronounced influence in determining the sex of her young. According to a considerable body of statistics collected by Punnett ('03) the sex ratio among the first children in a family is 140 boys to 100 girls. This ratio falls to 117 boys to 100 girls for the second births among the children of these same mothers, and it then declines steadily until, at the ninth birth, the chances for the two sexes are about even. In a compilation of birth statistics for the first born of women of various ages, Bidder ('78) found that the sex ratio was 122.2 boys to 100 girls when the mothers were under 19 years of age; this ratio falls to 104.6 boys to 100 girls for the children of women between 20-30 years of age and it then rises to 131 boys to 100 girls when the first conception occurs after the woman has reached 40 years of age. Conditions closely paralleling these for man are found in the horse according to Wilckens, but this investigator states that heifers predominate among the first offspring of cattle.

Data given by Copeman and Parsons ('04) from their inbreeding experiments with mice show the relation between the age of the mother and the sex of the offspring as given in table 6. Normally there is about an equal proportion of the sexes in mice as is shown by the investigations of Schultze ('03) and of Welden ('06).

The sex records for the mouse, as given in table 6 , agree with those for man and for the horse in that they show that the sex ratio in the young is at its lowest point when the mother is at 
the height of her reproductive powers. Schultze, on the other hand, states that young female mice tend to produce a slight excess of females among their young, and he concludes that the age of the mother has no effect whatever on the sex of her offspring.

TABLE 6

Showing the effects of the age of the mother on the sex ratio of mice. Data collected by Copeman and Parsons

\begin{tabular}{|c|c|c|}
\hline $\begin{array}{l}\text { AGE OF FEMALE AT } \\
\text { CONCEPTION }\end{array}$ & $\begin{array}{l}\text { NUMBER OF } \\
\text { LITTERS }\end{array}$ & $\begin{array}{l}\text { NUMRER OF MALES } \\
\text { TO } 100 \text { FEMALES }\end{array}$ \\
\hline $2 \operatorname{mos} \ldots \ldots$ & 21 & 103.7 \\
\hline 3-5 mos... & 27 & 96.5 \\
\hline $6 \operatorname{mos} \ldots \ldots \ldots$ & 21 & 123.3 \\
\hline
\end{tabular}

For comparison with the records given by Copeman and Parsons and by others we have the sex data for 75 litters cast by 21 stock albino rats. These data, arranged according to the location of the litter in the litter series, are given in table 7 .

TABLE 7

Showing the sex ratios and average number of young in 75 litters of stock albino rats. Data arranged according to the position of the litters in the litter series

\begin{tabular}{|c|c|c|c|c|c|c|}
\hline LITTER SERIES & $\begin{array}{c}\text { NUMBER } \\
\text { OF } \\
\text { LITTERS }\end{array}$ & $\begin{array}{c}\text { NUMBER } \\
\text { OF } \\
\text { INDIVID- } \\
\text { UALS }\end{array}$ & MALES & FEMALES & $\begin{array}{c}\text { NUMBER } \\
\text { MALES TO } \\
100 \\
\text { TEMALES }\end{array}$ & $\begin{array}{c}\text { AVERAGE } \\
\text { NO. YOUNG } \\
\text { PER } \\
\text { LITTER }\end{array}$ \\
\hline 1. & 21 & 131 & 72 & 59 & 122.0 & 6.2 \\
\hline 2. & 21 & 162 & 85 & 77 & 110.4 & 7.7 \\
\hline 3. & 18 & 127 & 64 & 63 & 101.6 & 7.0 \\
\hline 4... & 15 & 96 & 41 & 55 & 74.5 & 6.4 \\
\hline & 75 & 516 & 262 & 254 & 103.1 & 6.8 \\
\hline
\end{tabular}

At the time that the first litter was cast each of the 21 females was about three months old. As shown in table 7 , the sex ratio in the young rats belonging to the first litters is 122.0 males to 100 females. For the individuals in the second litters the sex ratio drops to 110.4 males to 100 females, and it goes down to 101.6 males to 100 females for the rats belonging to the third litters. At the time that the females cast their fourth litters the majority of them were seven to nine months old. 
The female albino rat, if she is in good physical condition, will continue to bear young until she is about fifteen months old. The third and the fourth litters of an albino female, therefore, are usually cast during the period when the female is at the height of her reproductive power. In the above table the sex ratio for the fourth litters is much lower than that for the first three litters, being only 74.5 males to 100 females.

The records given in table 7 are, of course, too few to furnish evidence from which very definite conclusions can be drawn. As far as they go, however, these records indicate that the sex ratio among the first offspring of very young females is higher than that found among the offspring of the same females at a period of life when they are at the height of their reproductive power. The results, therefore, are in agreement with those obtained by Punnett, by Bidder and by Copeman and Parsons. In what way the age of the mother can affect the sex of her offspring is not known as yet. The fact that female rats at the height of their sexual activity in the spring and fall and also at the zenith of their reproductive power tend to produce relatively more female than male young would seem to indicate that the physical condition of the female, either as the result of age or of environment, produces changes of metabolism that tend to affect the sex of the young. It is possible that anabolic processes predominating in the female at certain periods might affect the ova in such a way as to cause them to be more easily fertilized by a female-producing than by a male-producing spermatozoan. In very young females, on the other hand, and in females not in good physical condition, katabolic processes that would give the male-producing spermatozoa an advantage over the female-producing spermatozoa in the fertilization of the ova, might be assumed to occur. Until, however, our knowledge of the mechanism of sex determination rests on a more secure foundation than it does at the present time, it seems useless to offer even tentative suggestions as to the manner in which this mechanism can be influenced. 
THE RELATION BETWEEN THE SIZE OF A LITTER AND THE SEX OF ITS MEMBERS

Evidence for man as to whether one sex or the other tends to predominate in large families is conflicting. According to Nichols ('07), it has been shown by several investigators, particularly by Geissler ('89), that in large families there is a greater proportion of sons than in small families. Geissler's statisties show that in 159,042 families containing more than seven children the sex ratio was 106.8 boys to 100 girls, while in 839,719 families having from two to seven children each there were only 105.8 boys to 100 girls. From the statistics of a very much smaller number of families, Punnett ('03) comes to the opposite conclusion that girls tend to predominate more in large families than in small ones.

Copeman and Parsons's breeding experiments with mice show that the percentage of males is slightly less in large litters (containing more than 6 young) than it is in small litters. Welden, on the contrary, states that in a given generation of mice there seems to be a positive tendency for large litters to contain more males than females.

The sex data for 1089 litters of albino rats have been arranged on the basis of litter size in order to ascertain if, in this animal, there is any relation between the sex of the individuals and the size of the litters to which they belong. For the purpose of this analysis the litters have been arbitrarily divided into three groups: large litters containing nine or more young; medium litters with six to eight young; small litters having five or less members. The records collected during the year 1914 are sufficiently numerous to warrant their separation into groups according to the months when the litters were cast; the data obtained during 1911-1913, being too few to be divided in a similar way, have been grouped together. The results of this arrangement of data are given in table 8 .

As shown in table 8 , the results obtained by this analysis are so conflicting that no definite conclusions can be drawn from them. The data for the year 1914, arranged according to the months when the litters were cast, show that the highest sex 
TABLE 8

Showing the sex ratio in different sized litters of albino rats. Data collected during 1914 arranged according to the months when the litters were cast

\begin{tabular}{|c|c|c|c|c|c|c|}
\hline \multirow[b]{2}{*}{ MONTHS } & \multicolumn{2}{|c|}{9 OR MORE YOUNG } & \multicolumn{2}{|c|}{6 TO 8 YOUNG } & \multicolumn{2}{|c|}{5 OR LESS YOUNG } \\
\hline & $\underset{\text { Number }}{\text { Nitters }}$ & $\begin{array}{c}\text { Number } \\
\text { males to } \\
100 \\
\text { females }\end{array}$ & $\begin{array}{c}\text { Number } \\
\text { litters }\end{array}$ & $\begin{array}{c}\text { Number } \\
\text { males to } \\
100 \\
\text { females }\end{array}$ & $\underset{\text { litters }}{\text { Number }}$ & $\begin{array}{c}\text { Number } \\
\text { males to } \\
100 \\
\text { females }\end{array}$ \\
\hline January..... . & 14 & 108.7 & 27 & 93.1 & 16 & 91.7 \\
\hline February...... & 19 & 98.9 & 25 & 87.6 & 12 & 87.5 \\
\hline March........ & 24 & 87.1 & 22 & 98.7 & 12 & 125.0 \\
\hline April......... & 14 & 112.3 & 24 & 144.3 & 13 & 75.8 \\
\hline May.......... & 23 & 104.6 & 19 & 85.9 & 18 & 126.5 \\
\hline June... & 34 & 100.6 & 42 & 109.9 & 25 & 131.3 \\
\hline July........ & 36 & 97.7 & 56 & 120.6 & 24 & 116.7 \\
\hline August... & 29 & 129.9 & 57 & 134.1 & 23 & 111.4 \\
\hline September. . & 28 & 100.0 & 46 & 98.1 & 37 & 107.8 \\
\hline October...... & 1 & 125.0 & 18 & 119.3 & 12 & 140.9 \\
\hline November.... & 3 & 93.8 & 15 & 123.4 & 15 & 100.0 \\
\hline \multirow[t]{2}{*}{ December........... } & 3 & 130.8 & 15 & 106.3 & 13 & 133.3 \\
\hline & 228 & 103.7 & 366 & 110.7 & 220 & 111.7 \\
\hline Data for $1911-1913$. & 65 & 109.9 & 142 & 110.5 & 68 & 90.2 \\
\hline Total. & 293 & 106.8 & 508 & 110.6 & 288 & 100.7 \\
\hline
\end{tabular}

ratio occurs in the members of the largest litters in only two cases, while in six cases it is found in the individuals comprising the smallest litters. In the records for the entire year the highest sex ratio, 111.7 males to 100 females, occurs in the individuals composing the smallest litters; the lowest sex ratio, 103.7 males to 100 females, being found in the rats belonging to the largest litters. The records for 1911-1913, on the other hand, give the highest sex ratio, 110.5 males to 100 females, in the individuals belonging to litters of medium size; the records for the small litters show a sex ratio of only 90.2 males to 100 females. For the entire series of data, litters of medium size show the highest. sex ratio, 110.6 males to 100 females, and the lowest sex ratio occurs in the individuals of the small litters.

The lack of uniformity in the results of this arrangement of data indicate that apparently there is no well defined relation between litter size and sex in the albino rat. 
THE NORMAL SIZE OF THE LITTER IN ALBINO RATS

Available data concerning litter size in the rat indicate that the average number of young in a litter varies considerably in different species. Miller ('11) finds for the common gray rat (Mus norvegicus) that there is a range of 7 to 12 young in the litter and that, on the average, a litter contains 10.5 young. Data recorded by Lantz ('10) give 8.1 as the average number of young in a large series of pregnant females of this species killed in India. Litters of the black rat (Mus rattus) are apparently much smaller than those of the gray rat. Lantz states that 5.2 young is the average for the litters of this species. This average is practically the same as that given by Lloyd ('09).

But few observations have been recorded regarding litter size in the albino rat. Crampe ('84) states that the average size of a litter of albino rats is 5.6 young, which is exactly the result obtained by one of us (King '11) from an examination of 80 litters of stock albino rats. Cuénot records 8.5 as the average number of young in 30 litters of albino rats, but this is undoubtedly a higher average than would be found in a larger series of litters.

In addition to the sex ratios tables $1-4$ give the average number of young in the various litters examined during the years 1911-1914. The records for the period from 1911-1913, as given in table 1, show that there is very little variation in litter size in the various groups of litters cast during the different months of the year; the range being from 6.3 young, the average size of the litters cast during April, to 7.5 young, the average of the litters produced during December. The largest litter examined contained 14 young, the smallest contained only two individuals. For the series of 275 litters the average size of the litter was 7.01 young.

A similar analysis of the data collected during the year 1914, as given in table 2, shows for the entire series of 814 litters an average of 6.99 young per litter, which is remarkably close to the average for the litters examined in 1911-1913. While the records for 1914, as a whole, show a great uniformity in the 
average size of the litters cast in the various months, there seems to be a tendency for the litters cast during the first part of the year to be slightly larger than those produced during the latter half of the year. A similar tendency, however, is not noted in the records of table 1 , so that it can have little, if any, significance.

Records for the entire series of 1089 litters give 7.0 young as the average number of individuals in a litter. According to these observations, therefore, the size of a litter of albino rats is, on the average, greater than that of the black rat, but it is smaller than that in the gray rat of which it is the domesticated variety.

The data for litter size, arranged according to the season of the year when the litters were cast, are given in table 4 . A marked uniformity in the various series of records is again evident. In the final averages the litters cast during the fall of the year show a relatively small size. This result probably has little, if any, meaning, since it is due entirely to the low average size of many of the litters cast during the fall of 1914. Records for the litters cast in corresponding months of the years 19111913 give 7.0 young as the average number of individuals per litter. It is evident, from these results, that there is no pronounced seasonal variation in the size of the litters at all comparable to the evident change that occurs in the sex ratio at stated periods in the year. Seasonal changes in the sex ratio are independent of litter size just as the normal sex ratio is independent of litter size.

Crampe ('83) states that the first litter of an albino rat is not as large as the second and that the second litter is an index of the size of subsequent litters. The first part of this statement can be corroborated by our records, but the latter part of it needs to be modified. A large second litter gives no indication whatever as to the size of the following litters, as the records for litters from many hundreds of females collected by one of us shows. In many cases a large second litter is followed by an unusually small litter, and there are marked individual differences in females regarding the size of the litters they pro- 
duce. Some females never have over five or six young in a litter; other females invariably cast litters containing eight or more young.

The average size of 75 litters cast by 21 stock albino rats is given, with other data, in table 7 . In these records the average size of the first litter is found to be considerably less than that of the second, while the second of the four litters is the largest of the group, containing an average of 7.7 young per litter. In this particular series of records the average size of the third litters is considerably below that for the second litters, but in a larger series of data it would probably be found that the third litter is nearly, if not equal, to the second in size. The fourth litters are, as shown in table 7, only a little larger than the first, as a rule.

For the entire series of 75 litters the sex ratio is below normal, and the average size of the litters is somewhat small, being only 6.8 young per litter. The number of young in a given litter is dependent to a marked extent on the age and physical condition of the female (King '15), and it is not improbable, as previously stated, that these factors also have an effect on metabolic processes that play an important rôle in determining the sex of the embryo.

\section{SUMMARY}

1. Albino rats breed throughout the entire year, but the periods of greatest sexual activity are in the spring and autumn.

2 . The sex ratio in the 1089 litters of albino rats examined was 107.5 males to 100 females.

3 . There is, apparently, a seasonal variation in the sex ratio of the albino rat. Litters cast in the spring and early fall show a relatively low sex ratio; those cast in summer have a much higher sex ratio (fig. 1).

4. Data for 75 litters produced by 21 albino females indicate that the sex ratio among the first offspring of young females is higher than that found among the offspring of the same females when they are at the height of their reproductive power. 
5. There is apparently no relation between the size of a litter of albino rats and the sex of its members.

6. The 1089 litters examined contained an average of 7.0 young per litter. Litters of albino rats, therefore, are smaller than those of the gray rat and larger than the litters of the black rat.

7. There is no pronounced seasonal variation in the litter size comparable to the seasonal variation noted in the sex ratios.

8. As a rule the first of an albino female's four litters is the smallest; the second and the third litters are the largest: the fourth litter is a little larger than the first. 


\section{ILITERATURE CITED}

Bidder, F. 1878 Ueber den Einfluss des Alters der Mutter auf das Geschlecht des Kindes. Zeitschr. Geburtshülfe und Gynäkologie, Bd. 11.

Copeman, S. M., and Parsons, F. G. 1904 Observations on the sex in mice. Proc. Royal Soc. London, vol. 73.

Crampe, H. 1883 Zucht-Versuche mit zahmen Wanderratten. I. Resultate der Zucht in Verwandtschaft. Landwirthschaftliche Jahrb., Bd. 12. 1884 Zucht-Versuche mit zahmen Wanderratten. II. Resultate der Kreuzung der zahmen Ratten mit wilden. Landwirthschaftliche Jahrb., Bd. 13.

Cú́not, L. 1899 Sur la determination du sexe chez les animaux. Bull. Sei. de la France et de la Belgique, t. 32 .

Düsıng, K. 1884 Die Regulierung des Geschlechtsverhältnisses bei den Vermehrung der Menschen, Tiere und Pflanzen. Jen. Zeitschr. Natur. Wiss., Bd. 17.

Geissler, A. 1889 Beiträge zur Frage des Geschlechtsverhältnisses der Geborenen. Zeitschr. d. k. sächsischen statistischen Bureaus, Dresden, Bd. 35.

Heape, W. 1908 Notes on the proportion of the sexes in dogs. Proc. Cambridge Phil. Soc., vol. 14.

JACKSON, C. M. 1912 On the recognition of sex through external characters in the young rat. Biol. Bull., vol. 23.

King, Helen Dean 1911 The sex ratio in hybrid rats. Biol. Bull., vol. 21. 1915 On the weight of the albino rat at birth and the factors that influence it. Anat. Rec., vol. 9.

Lantz, D. E. 1910 Natural history of the rat. U. S. Bull. Public Health and Marine Hospital Service.

LLOYD, R. E. 1909 Relation between fertility and normality in rats. Report of the Indian Museum, vol. 3.

Miller, N. 1911 Reproduction in the brown rat (Mus norvegicus). Amer. Nat., vol. 45 .

NichoLs, J. B. 1907 The numerical proportions of the sexes at birth. Mem. Amer. Anthropological Assoc., vol. 1.

Punnetr, R. C. 1903 On nutrition and sex-determination in man. Proc. Cambridge Phil. Soc., vol. 12.

Schlechter, J. 1884 Ueber die Ursachen welche das Geschlecht bestimmen. Biol. Centralbl., Bd. 4.

Schultze, O. 1903 Zur Frage von den Geschlechtsbildenden Ursachen. Arch. mikr. Anat., Bd. 43.

WELDEN, W. F. R. 1906 On heredity in mice. I. On the inheritance of the sexratio and of the size of the litter. Biometrika, vol. 5 .

Wilckens, M. 1886 Untersuchung ueber das Geschlechtsverhältniss und die Ursachen der Geschlechtsbildung bei Haustieren. Biol. Centralbl., Bd. 6. 